\title{
13 Integration, fragmentation, and complexity
}

\author{
Governing the teaching profession and \\ the Nordic model
}

Wieland Wermke and Tine S. Prøitz

\section{Introduction}

National and regional variations in Nordic school systems and elsewhere have traditionally been explained in terms of their input or output governance strategies. The latter are often associated with 'standard-based reforms' designed to control schools' outputs through standard-setting and school evaluation. These approaches emphasise competition or so-called choice policies, which establish quasi-markets within the education system by, for example, shifting from supply to demand financing. By contrast, input-oriented regimes are often associated with centralised regulation of inputs, such as economic resources, detailed curricula, and standardised professionalisation of teachers. There is today, considerable room for multiple and hybrid versions of school governance in which individual teachers, principals, students, or parents influence the direction of development (SteinerKhamsi and Waldow, 2012; Frostensson, 2015; Wermke and Prøitz, 2019). The emergence of hybrid forms of governance lays the groundwork for recognising the formation of a conglomeration of influences rather than a singular, state-based form of governance. By comparing the teaching profession across three countries from a sociohistorical perspective, we suggest an approach to understanding national teaching professions that emphasises not only the input-output dichotomy, but also the varying degrees of complexity of these governance regimes. We understand complexity in terms of how the components of particular systems interact in contingent and multiple ways (Kauko and Wermke, 2018).

The more entities involved in a system - stakeholders with particular expectations and differing evaluation technologies - the more potential solutions for systemrelevant problems are probable. The more solutions there are, the higher the risk of teachers choosing the wrong ones. Reform strategies, including various levels of fragmentation and integration, produce different levels of complexity that national teaching professions must manage. Complexity in teachers' working lives becomes an issue of risk management: decision-making increasingly aims to minimise the possible risks associated with wrong decisions which might lead to sanctions of different kinds. An example of complexity and risk management is what Wermke and Salokangas (2021) call the 'autonomy paradox': the more the decisions to be made and the greater the number of stakeholders involved, the more the teachers may restrict themselves in order to reduce the risk of doing something wrong.

DOI: $10.4324 / 9781003082514-17$ 
The three countries compared in this chapter are Sweden, Norway, and Germany. For the purpose of our comparison, Sweden and Norway represent the Nordic context, while Germany has been included as a contrasting context outside the Nordic setting. We argue that there is no uniform Nordic teaching profession, even if there is a guiding Nordic ideology of universalism and equality in welfare systems, in which education continues to play an important role (Prøitz and Aasen, 2017). Despite their shared Nordic heritage, we argue that Sweden and Norway differ considerably in their methods of school system regulation - indeed, Norway more closely resembles the German case, which, as a highly stratified, organisationally differentiated, education system, does not have many Nordic-model features at all. ${ }^{1}$ Moreover, all three countries have undergone education reforms, but in different ways and at different times. Our comparison will reveal the complementary relationship between output and input strategies, and a pattern of more and less complex multi-governance relationships (Frostensson, 2015).

\section{Swedish teachers: rolling reforms, politicisation, and marketisation}

The Swedish education reform in the 1980s and the 1990s was a two-step process (Lundahl et al., 2010): decentralisation, which involved handing over responsibility for schools to municipalities; and marketisation, which introduced free school choice. Decentralisation increased local autonomy and municipal responsibility for financial resources and the organisation of schools. For example, responsibility for teacher employment and salaries was transferred from the central government to municipalities. This was followed by a strong marketisation of the school system. The introduction of school vouchers, which expanded the parents' right to choose a school for their child, transformed the system. Technically, every pupil was given a school voucher which financed the school he or she attended. Teachers were also free to move around within the market. Traditionally strong unions, that were hitherto indicative of a strong corporative teacher culture, lost influence with marketisation and the decentralisation of teachers' work (Persson, 2008). By the early 1990s, teachers bargained for their salaries individually with their principals, and became dependent on the school's individual situation within the market. It has been argued that Swedish teachers shifted from being civil servants and having a civil servant ethos (Lundqvist, 1998) to becoming market actors (Fredriksson, 2010).

In the 1990s, there were few bureaucratic regulations on teachers, as long as the expected results were achieved. Moreover, goals and results were defined openly in the curriculum and syllabi. The main rationale for these reforms was that autonomous teachers in the schools were expected to contribute actively to the curriculum and to interpret the formulated goals and implement them in their local contexts (Carlgren, 2009). This also accelerated market mechanisms. The radical opening of the school system to new actors following marketisation and decentralisation was accompanied by collateral damage. A traditionally centralised and uniform system became increasingly segregated and too complex to 
monitor (Wermke and Forsberg, 2017). Moreover, since 2000, large-scale international assessment studies, such as the Programme for International Student Assessment (PISA) and Trends in International Mathematics and Science Study (TIMSS), have become increasingly important to Swedish policymaking. Disappointing results after the turn of the millennium showed declining performance among Swedish pupils. The state's response was to roll out strict recentralisation reforms with new control technologies. Since 2008, the government has increased school evaluation through an extended system of school inspectorates and national curriculum testing, increased the number of subjects, included more age cohorts in the testing procedure, and used the results more extensively in assessment (Rönnberg, 2011). Meanwhile, in schools, syllabi have not only become more structured and detailed, but also more prescriptive. Teachers today feel a cross-pressure from increased decision-making responsibilities and individualisation of their work on the one hand, and strict control regimes of different actors at the national and local levels, on the other (Wermke and Salokangas, 2021). In summary, the Swedish school system has become complex and highly fragmented.

The current situation must be understood against its historical backdrop. There has long been a close relationship between certain groups among Swedish teachers (elementary school teachers) and the politically dominant social-democratic movement. From early in its development, therefore, the teaching profession was heavily influenced by politics (Hartman, 2012). Within this social-democratic governance regime, politicians, policymakers, and educational researchers worked closely to govern schools. In other words, the modern Swedish mass schooling project has been highly politicised.This politicisation can be seen as the root of the complexity and fragmentation of the school system today. It can be argued that politicisation, together with decentralisation, actually accelerated fragmentation. Schooling today depends on the municipality in which it takes place, and which political group governs there. It has been shown that the municipal school administration has also become increasingly politicised (Bergh, 2015).

Another historical feature of the Swedish system, related to its high degree of politicisation, is a belief in ongoing school reform. Since the implementation of comprehensive schooling (grundskola) by 1962, the government has maintained a stream of school pilots and research projects, requiring constant evaluation and observation. This phenomenon has been described as a 'rolling reform' (Hartman, 2012), an expression of the continuing adjustment and development of the school system by the state. It can be argued that rolling reform has been the state's attempt to shape the relationship between teachers and the state. Therefore, change, or reaction to change, has become an essential part of the Swedish teaching profession over the past decades. Crucially, the rapid pace of reform over the last 30 years or more is likely to have generated feelings of insecurity and instability amongst teachers in an environment in which they are in a perpetual state of novicehood and dependency (Wermke, 2013). Moreover, this 'innovation fetishism' produces a multiplicity of practice, increasing complexity and fragmentation. 


\section{Norway: transformation towards output governance in a strong and universal welfare state}

In Norway, as in Sweden, an active state has traditionally regulated the educational system, including teacher education, and largely defines the premises of the teaching profession. Through national educational policy, the formation and operationalisation of a comprehensive public education system has helped to realise broader social goals, such as nation-building, economic growth, and a universal welfare system (Telhaug et al., 2006). Within this framework, the teaching profession is an important agent for achieving national policy goals and, consequently, a target of national education policy development, exemplified by numerous reforms and strategies. The last 20 years of intensive education reform have had particular influence on the formation of Norway's teacher culture today. The central elements of these reforms include the introduction of a more results-oriented education system and systems for assessment, combined with a stronger accountability script within a decentralised system (Aasen et al., 2012). Following a period of decentralisation and governing based exclusively on learning outcomes and result-monitoring, policies strengthening central state control were implemented once more, resulting in a mosaic of governing by results, regulations, supervision, various support systems and guidelines, school inspections, and professional development programmes (Prøitz and Aasen, 2017).

In the early reform period, starting in 2006, Norwegian teachers were influenced by new accountability policies that broke with the country's traditional low-stakes educational context. Still, Norway has not put into place the characteristic high-stakes follow-up mechanisms, such as incentives and rewards, found in, for instance, the United States. On this basis, it can be argued that Norway has only moved partway toward an accountability system. The country's reform efforts can be described as an attempt to navigate the tensions between accountability and answerability - with the aims both to reach short-term goals and to fulfil broader purposes - as well as to build capacity for both (Hatch, 2013). Furthermore, the new policies, which emphasise external control of teachers' work, challenge traditional trust in, and autonomy of, teachers (Mausethagen, 2013). Teachers also report being affected by the accountability movements introduced by the latest reforms (Mausethagen et al., 2018). Still, Norwegian teachers today perceive themselves as a rather autonomous occupational group, possibly because of the relatively lowstakes policy, strong teacher unions, and the orientation towards consensus, which requires the involvement of stakeholder groups in policymaking (Helgøy and Homme, 2007; Prøitz and Aasen, 2017).

When new ways of governing Norwegian education were introduced with the so-called Knowledge Promotion Reform (Kunnskapsløftet) in 2006, the Norwegian school system had little experience with working with predefined learning outcomes and assessment (Lysne, 2006), as a strongly process-oriented tradition had dominated (Engelsen and Smith, 2010). The introduction of a new curriculum with a learning outcome rationale paved the way for a stronger assessment regime consisting of national curriculum tests, diagnostic and mapping tests, revisions to 
the national regulations for assessment, and an intensive government-initiated campaign to enhance the practice of formative assessment. These trends were similar to those seen in Sweden.

Today, Norway is again at the threshold of a new curriculum reform, officially starting in 2020/2021. Fagfornyelsen, or 'the renewal of school subjects', is inspired by the international twenty-first-century skills movement, and introduces broader competency goals, an emphasis on 'deep learning', and three specified multidisciplinary topics: public health and life skills, democracy and citizenship, and sustainable development. Within this new development in education policy, teachers are considered as change agents and framed by expectations that they should be both controlled and autonomous in education reform (Prøitz, Rye and Aasen, 2019). On their side, teachers and school leaders report that they have, in recent years, developed a stronger focus on nationally defined learning goals and assessment. Teachers describe their daily work as characterised by a balancing act between fulfilling the requirements of the formal system in terms of national examinations and final grading on the one hand and, on the other, professionally developed ways of teaching within an education system oriented towards learning outcomes (Mølstad, Prøitz, and Dieudé, 2020). This duality underscores how Norwegian teachers must balance the requirements of state governance with their professional ways of working in schools.

The shifts that the current reforms represent for the Norwegian teaching profession are shaped by certain characteristics of its past (Thue, 2017). In 1889, Norway introduced a comprehensive elementary school system, a social equality initiative that took place earlier than in most other countries in Europe. The introduction of this system sparked a growing debate on the kinds of teachers it required. Since then, debates about qualifications for both primary- and secondary-school teachers, and where they should be educated, have recurred (Grotnæss, Sundet and Øygarden, 1982; Garm and Karlsen, 2004). Since 2017, all teacher education requires master's-level qualifications obtained at a university or university college.

Norway has thus had a strong dynamic towards a more integrated and comprehensive professionalisation of primary- and secondary-school teachers (see Chapter 10). Its development can be understood by looking at how the education system, including teacher education, have been coordinated and reformed in parallel by successive governments within a political system characterised by a high degree of consensus regarding educational issues, and with strong cooperative traditions. This historical development provides the basis for a more unified teaching profession and teacher education today. Simultaneously, and in contrast to the move towards more integrated and unified teacher education, tensions have emerged between the expectations of the state and professional ways of working in schools. In regard to how these tensions are handled, a blended teacher culture is apparent, in which teachers have developed professional ways of handling both the requirements of the state and the requirements of the profession.

The state has continuously had a strong role in the development of the teaching profession, from earlier times to today, but its governing has also been characterised by dialogue and collaboration, negotiation and compromise. We might argue, 
therefore, that the Norwegian case is not as politicised as the Swedish. This might reflect the difference between the rapid and radical change towards an education system with more private schools owned by private companies, which we find in Sweden, and the scepticism that meets such developments in Norway. This scepticism illustrates how openings for more private schools and new education markets challenge the public universal education system, as well as the collaborative traditions that exist between policymakers and the teaching profession in Norway. Close integration between the state, municipalities, and schools, paralleled by strong unions, a cooperative democratic tradition, and orientation towards consensus in policymaking, can be seen as a continuation of the idea of education as a central part of the welfare system and the nation-building project after the Second World War (Telhaug et al., 2006).

\section{German teachers: organisational differentiation and bureaucracy}

In the Federal Republic of Germany, education is the responsibility of the federal states (Bundesländer). There are thus certain regional differences in schooling and teaching cultures. However, since the Bundesländer work together on educational issues, and are obliged to harmonise their systems, the main structures, such as school governance, and crucial educational traditions and trends, are quite similar (Tenorth, 2008).

Furthermore, when discussing the teaching profession, the division of the German school system into different school types with different kinds of teachers must be taken into account. The school system has separate paths for pupils performing at different levels. Children are instructed together at an elementary school (Grundschule) up to the fourth, fifth or sixth grade, depending on which Bundesland they live in. The pupils are then assigned to different schools based on academic performance, with parental involvement. The central idea is that homogeneous groups form the best foundation for successful education (Diederich and Tenorth, 1997). Therefore, unsurprisingly, Germany also has a highly complex system of special schools for students with various needs. This academic-performance-based system of organisational differentiation is based on grading and teacher recommendations, illustrating the significant responsibility that teachers have early in students' educational careers. Consequently, if a Nordic model of education draws on the idea of universalism and equal opportunity, the German system displays the opposite: organisational differentiation and meritocracy.

German teachers are mostly tenured civil servants (Beamte) employed by the federal state. The federal state also regulates, examines, and certifies teacher education. The civil service structure of the teaching profession can also be seen in initial teacher education, which involves state examinations. The assessment of teaching skills by the seminary heads involves a series of demonstration lessons. This, alongside the prevalence of didactic reasoning (e.g., Klafki's [2000] didactic analysis) as the master plan for lesson planning, leads to a standardisation of teachers' work. Since it is the state that has the overall responsibility for teacher examinations, these have been termed state examinations. Wermke and Paulsrud (2019) argue that the German form of teacher training has a strongly integrative character. 
These very traditional structures have been affected by different reforms since 2000, mostly to do with accountability (Thiel, 2019). At the beginning of the 2000 s, the shock of German pupils' low rankings in large-scale international studies of student performance, such as the PISA tests, led to a national response. Traditionally, the state has governed the inputs to the school system through the consistent distribution of resources and teacher education, thereby regulating the process of schooling. Since the early 2000 s, there has been a shift toward output control. This has meant the implementation of tests based on the central curriculum, and central examinations (Zentralabitur) in all German states. However, schools have also gained more autonomy in certain areas. Principals are allowed to use some of their resources more freely and employ more teachers according to their schools' needs. Their responsibilities related to staff development have also increased. This kind of school autonomy was not possible before. All this also implies that teachers and schools today are more accountable for their pupils' performance on standardised curriculum tests and central examinations (Thiel, 2019).

However, despite these reforms, the German education system has not undergone a total 'paradigm shift' (Thiel, 2019). Teachers remain (in most states) tenured civil servants. Although the reforms rolled out in Germany were intended to improve school results through competition, the results of curriculum testing are not made public. Germany does not have a market-regulated school system where schools receive resources based on the number of pupils enrolled, as in Sweden. The reforms have been keenly debated, and the new public management ideology has not been embraced by German teachers and their traditional civil service structures (Terhart, 2011).

Historically, the resilience of traditional structures, even in the face of strong international trends towards reform, is unsurprising. In the nineteenth century, teachers were not controlled by a clerical school inspectorate, but were subordinate to or even part in the Prussian state administration. The state formulated the curriculum and certified teachers' competence through a state exam. By the turn of the twentieth century, a second part of teacher education, which had a didactic and practical focus and was led by expert teachers, became mandatory for secondaryschool teachers. This part was also examined by the state (Lundgreen, 2011). The secondary schools were autonomous organisations, in which teachers exercised their judgement about teaching content and methods, as well as more general issues, such as student recruitment and admissions (Tenorth, 1996). Consequently, German teachers have also been considerably secured from political trends and a severe politicisation of the school system.

This considerable decision-making capacity at the school level, and the status of teachers as equivalent to senior civil servants, are today important pillars of the German teaching profession (Lundgreen, 2011). Formal status is also something that elementary school teachers (Volksschullehrer) strived for and, in the second half of the twentieth century, were granted by the state. Consequently, the German teaching profession is closely related to state administration but is licensed to teach and run schools autonomously. This historically based teacher privilege was legitimised through teacher training at seminaries. Didactic reasoning was the language for legitimising teachers' interpretation of the curriculum in practice (Hopmann, 
2003), but was also an effective way of standardising and shaping teacher practice, following Herbart's and his successors' models of educational practice (Wermke, 2013). This regulated and structured the system of teacher education and licensed teachers according to the state's requirements. The teaching 'license' was, therefore, an integrative instrument. Such extended training required significant resources, but by incorporating standards, norms, and competence into teacher training, the state was able to save on costs related to extensive teacher monitoring. This also resulted in the desired displacement of the church as the main organisation responsible for people's education (Hopmann and Künzli, 1992).

Time has proven the stability of the German teaching profession. The First and Second World Wars did not bring significant changes to its governance (Tenorth, 2008), nor did the end of the National Socialist regime. There were no significant changes during the educational expansion of the 1970s (Terhart, 1998), or after reunification and the incorporation of the East German comprehensive school system in 1990 (Gehrmann, 2003). The stability of the German structures and their underlying bureaucratic traditions stand in striking contrast to the lively history of reform in Sweden and Norway. In Germany, tradition can be seen as integrating and complexity-reducing (Kauko and Wermke, 2018).

\section{Discussion}

Our exploration of the education systems of three countries reveals a variety of relationships between states, municipalities, principals, teacher education, and the teaching profession. In the words of Frostensson (2015), teachers must navigate 'multiple governance relationships'. These different actor configurations are important for the understanding of national teaching professions in the Nordic countries and elsewhere in Europe. Using the sociohistorical perspective employed in this chapter, we have traced aspects of output and input governance, as well as their hybridisation, in these three education systems. The German system can be described as a more input-governed regime than the two Nordic cases, while Sweden employs many more techniques of output governance and Norway falls between the two.

Swedish teachers operate within a highly complex system. Radical decentralisation and marketisation reforms since the 1990s have resulted in a confusing system, which tends to blend together many different ideas of what schools and schooling can look like. This has fragmented and increased the complexity of the Swedish system significantly (Wermke and Forsberg, 2017), and is driven by the marketisation and politicisation of the school system. The integrating aspects of the Swedish teaching profession have disappeared, such as strong unions as corporate political actors, and the corporate identity of teachers as civil servants within a stable state bureaucracy. In recent years, the state has started to recentralise its school system, most visibly with the implementation of rigid school inspections and registration for teachers. There is also a growing emphasis on testing for the national curriculum.

However, it is important to remember that in such reform processes, centralised governance is not simply replaced by decentralised governance and then recentralised again. Instead, it is common for hybridised systems to emerge from such 
back-and-forth processes. Indeed, after a vast number of reforms, Swedish teachers must now relate in their professional practice to a plethora of governance instruments and are accountable to numerous stakeholders with varying expectations. Historically, Swedish teachers have been used to political reform pressure from above. The phenomenon of rolling reforms has long been a significant feature of the system. This distinctively Swedish pattern, which we might call innovation fetishism, constantly introduces significant new reforms with consequences for teachers' practice, rendering the profession highly dependent on political change. The danger of fragmentation has consequently long been part of the teaching profession's DNA and has provided a fertile ground for radical change in Sweden since the 1990s.

Although similar to some extent, the Norwegian case is less complex. Education here is more streamlined because of the strongly consensus-oriented style of state governance and a comparatively unified teacher education and school system. Nevertheless, the state's strong governance has also produced tensions. A multitude of governing tools are applied, ranging from a competencebased national curriculum to school inspections. There are several stakeholder groups whose interests must be accommodated, and autonomous local authorities with varying governing and financial capacities. There is thus some complexity in the forms of state governance, local autonomy, accountability, and responsibility. Within this context, the teachers are exposed to a high degree of pressure around student performance, while also retaining a high degree of autonomy around teaching and classroom activities. Thus, Norwegian teachers operate within a strong government-defined framework of formal education and teacher education, with a multitude of supporting measures; however, the co-existence of a diversity of expectations from different levels, institutions, and stakeholders also generates complexity and tensions. Historically, Norwegian teachers have been trained for and are used to handling a blend of external requirements and internal responsibilities within an integrated and - certainly in comparison to Sweden low-stakes professional context.

Finally, Germany is an interesting comparative case to the two Nordic countries, and serves to illuminate our arguments about complexity. The German system has also been influenced by international trends, such as accountability and monitoring cultures. However, the German system was highly complex even before accountability reforms were introduced. German teachers work in a tracked system in which students are sorted based on academic ability. Such a system has significant consequences, for example, on grading and assessment practices. Since different kinds of schools are related to different life chances for students, German teachers bear great risks for their decisions in classrooms and the school. However, teachers can utilise various robust, historically based coping strategies to diminish such complexity. The German system is heavily bureaucratised, which influences teachers' work in the face of such heavy decisions. Their close relationships with the state, as civil servants, give German teachers a robust basis for manoeuvre. These historical particularities, which have been stable for over 120 years, have enabled teachers to defend their profession against accountability-oriented school reforms. Even when PISA results showed up the shortcomings in the German system, such 
as mediocre student performance, resulting in a 'PISA shock' (Ertl, 2006) and efforts to reform, the underlying structure of the German teaching profession remained largely unchanged (Wermke, 2013).

This leads us to conclude that, in order to understand all the hybrid forms of education governance we see today, we must introduce complexity as a sociohistorical concept. A historically grounded comparison of complexity in school systems - combining knowledge from multiple fields, such as teacher professionalism, education, and education policy - is a fertile way of comparing different national teaching professions. Complexity can then be both described and encountered through processes of integration and fragmentation.

In relation to the Nordic model, these arguments might be understood as follows: in recent decades, both Norwegian and Swedish teachers have experienced a transition towards more output-oriented, accountability-based governance regimes. Even German teachers have encountered reform attempts. The Swedish strategy of addressing reforms using radical decentralisation and marketisation, accompanied by strong politicisation, has led to a fragmentation of the school system (Wermke and Forsberg, 2017). The Norwegian system does not allow for such a multiplicity. Like in the German system, we see more integrating strategies, and teachers have a corporate identity as civil servants (Wermke and Prøitz, 2019). Moreover, the school administration is relatively less politicised. In both aspects, Germany resembles the Norwegian case.

The Norwegian case is also characterised by the stronger role of national authorities in education governance. A strong state in the reform processes has had an integrating effect and has therefore led to lower complexity for the Norwegian teaching profession. It remains to be seen if recently introduced governance technologies will prove sustainable in Norway, which has not been the case in the German system (Terhart, 2011). Other structures have remained sustainable, which has prevented the significant increase in complexity seen in Sweden. Bureaucratic structures, based on hierarchy and Didaktik (a particular system of reasoning), are still important conditions of the German teaching profession. In 1988, Hopmann presented the term Bürodidaktik (administrative didactics), which, within the frame of curriculum administration, ties the practice of teaching to an administrative logic provided by state governance. This phenomenon has proven to be highly integrative and sustainable, at the price, however, of reform inertia (Wermke, 2013). However, it is also something that has made German educational complexity manageable, even amidst various crises.

Our comparative analysis leads also to the conclusion that there is no uniform Nordic teacher model today. There is still a guiding idea of a Nordic model in education in terms of universalism and equality (Prøitz and Aasen, 2017), but the ways of reaching such goals with the help of national teaching professions differ for a number of social and historical reasons. The Nordic countries vary in terms of integration and fragmentation, at least in relation to education reform. The ideational basis of a hypothetic Nordic model is similar in both Nordic countries, but the means to achieve them differ, and thereby also the shape and practices of national teaching professions and their practice (Schulte and Wermke, 2019). That is why it is possible that the German and Norwegian teaching professions are 
rather similar, even though the German system, with its many forms of organisational differentiation, stands in strong contrast to the Nordic model.

\section{Note}

1 That this is provided by different perspectives on the (welfare) state is, as shown by Esping-Andersen (1990), obvious, but will not be elaborated further in this chapter.

\section{References}

Aasen, P., Møller, J., Rye, E., Ottesen, E., Prøitz,T. S. and Hertzberg, F. (2012) Kunnskapsloftet som styringsreform - et loft eller et lofte? Forvaltningsnivånes og institusjonenes rolle $i$ implementeringen av reformen (Report 20). Oslo: Nordisk Institutt for studier av innovasjon, forskning og utdanning (NIFU).

Bergh, A. (2015) 'Local educational actors doing of education - a study of how local autonomy meets international and national quality policy rhetoric', Nordic Journal of Studies in Educational Policy, 1(2). doi: 10.3402/nstep.v1.28146.

Carlgren, I. (2009) 'The Swedish comprehensive school - lost in transition', Zeitschrift für Erziehungswissenschaft, 12(4), pp. 633-649. doi: 10.1007/s11618-009-0103-1.

Diederich, J. and Tenorth, H.-E. (1997) Theorie der Schule. Berlin: Cornelsen Scriptor.

Engelsen, K. and Smith, K. (2010) 'Is “excellent” good enough?', Education Inquiry, 1(4), pp. 415-431. doi: 10.3402/edui.v1i4.21954.

Ertl, H. (2006) 'Educational standards and the changing discourse on education: the reception and consequences of the PISA study in Germany', Oxford Review of Education, 32(5), pp. 619-634. doi: 10.1080/03054980600976320.

Esping-Andersen, G. (1990) Three worlds of welfare capitalism. Cambridge: Polity Press.

Fredriksson, A. (2010) Marknaden och lärarna. Hur organiseringen av skolan påverkar lärares offentliga tjänstemannaskap. Gothenburg: Gothenburg University.

Frostensson, M. (2015) 'Three forms of professional autonomy: de-professionalisation of teachers in a new light', Nordic Journal of Studies in Educational Policy, 1(2), 28464. doi: 10.3402/nstep.v1.28464.

Garm, N. and Karlsen, G.E. (2004) 'Teacher education reform in Europe: the case of Norway; trends and tensions in a global perspective', Teaching and Teacher Education, 20(7), pp. 731-744. doi: 10.1016/j.tate.2004.07.004.

Gehrmann, A. (2003) Der professionelle Lehrer. Muster der Begründung - Empirische Rekonstruktion. Opladen: Leske und Budrich.

Grotnæss, I., Sundet, O. and Øygarden, S. (1982) Søkelys på praktisk larerutdanning - Pedagogisk seminar $i$ Oslo 75 ar. Oslo: Universitetsforlaget.

Hartman, S.G. (2012) Det pedagogiska kulturarvet (2nd rev. ed.). Stockholm: Natur \& Kultur.

Hatch, T. (2013) 'Beneath the surface of accountability: answerability, responsibility and capacity-building in recent education reforms in Norway', Journal of Educational Change, 14(2), pp. 113-138. doi: 10.1007/s10833-012-9206-1.

Helgøy, I. and Homme, A. (2007) 'Towards a new professionalism in school? A comparative study of teacher autonomy in Norway and Sweden', European Educational Research Journal, 6(3), pp. 232-249. doi: 10.2304/eerj.2007.6.3.232.

Hopmann, S. (1988) Lehrplanarbeit als Verwaltungshandeln. Kiel: Institut für die Pädagogik der Naturwissenschaften (IPN).

Hopmann, S. (2003) 'On the evaluation of curriculum reforms', Journal of Curriculum Studies, 35(4), pp. 459-478. doi: 10.1080/00220270305520. 
Hopmann, S. and Künzli, R. (1992) 'Didaktik-Renaissance', Bildung und Erziehung, 45(2), pp. 117-136. doi: 10.7788/bue-1992-0201.

Kauko, J. and Wermke, W. (2018) 'The contingent sense-making of contingency: epistemologies of change and coping with complexity in comparative education', Comparative Education Review, 62(2), pp. 157-177. doi: 10.1086/696819.

Klafki, W. (2000) 'Didaktik analysis as the core of preparation of instruction', in Westbury, I., Hopmann, S. and Riquarts, K. (eds.), Teaching as reflective practice. Mahwah, NJ: Lawrence Erlbaum, pp. 139-160.

Lundahl, L., Erixon Arreman, I., Lundström, U. and Rönnberg, L. (2010) 'Setting things right? Swedish upper secondary school reform in a 40-year perspective', European Journal of Education, 45(1), pp. 49-62. doi: 10.1111/j.1465-3435.2009.01414.x.

Lundgreen, P. (2011) 'Pädagogische professionen. Ausbildung und professionalität in historischer perspektive', Zeitschrift für Pädagogik, 57, pp. 9-39.

Lundquist, L. (1998) Demokratins väktare. Ämbetsmannen och vårt offentliga etos. Lund: Studentlitteratur.

Lysne, A. (2006) 'Assessment theory and practice of students' outcomes in the Nordic countries', Scandinavian Journal of Educational Research, 50(3), pp. 327-359. doi: 10.1080/ 00313830600743365.

Mausethagen, S. (2013) 'Reshaping teacher professionalism. An analysis of how teachers construct and negotiate professionalism under increasing accountability', $\mathrm{PhD}$ thesis. Oslo: Oslo and Akershus University College.

Mausethagen, S., Prøitz, T.S. and Skedsmo, G. (2018) Elevresultater: mellom kontroll og utvikling. Oslo: Fagbokforlaget.

Mølstad, C.E., Prøitz, T.S. and Dieudé, A. (2020) 'When assessment defines the content understanding goals in between teachers and policy', Curriculum Journal. doi: 10.1002/ curj.74.

Persson, S. (2008) Läraryrkets uppkomst och förändring: En sociologisk studie av lärares villkor, organisering och yrkesprojekt inom den grundläggande utbildningen i Sverige ca. 1800-2000. Stockholm: Arbetslivsinstitutet.

Prøitz, T.S. and Aasen, P. (2017) 'Making and re-making the Nordic model of education', in Nedergaard, P. and Wivel, A. (eds.), Routledge handbook on Scandinavian politics. London: Taylor \& Francis/Routledge.

Prøitz, T.S., Rye, E. and Aasen, P. (2019) 'Nasjonal styring og lokal praksis - Skoleledere og lærere som endringsagenter', in Jensen, R., Karseth B. and Ottesen, E. (eds.), Styring og ledelse i grunnopplaringen. Oslo: Cappelen Damm Akademisk.

Rönnberg, L. (2011) 'Exploring the intersection of marketisation and central state control through Swedish national school inspection', Education Inquiry, 2(4), pp. 689-707. doi: 10.3402/edui.v2i4.22007.

Schulte, B. and Wermke, W. (2019) Internationellt jämförande pedagogik. En introduktion. Stockholm: Liber.

Steiner-Khamsi, G. and Waldow, F. (2012) 'Policy borrowing and lending in education', World Yearbook of Education, 2012. London: Routledge.

Telhaug, A.O., Mediås, A. and Aasen, P. (2006) 'The Nordic model in education: education as part of the political system in the last 50 years', Scandinavian Journal of Educational Research, 50(3), pp. 245-283. doi: 10.1080/00313830600743274.

Tenorth,H.-E. (1996) 'Die professionelle Konstruktion der Schule - Historische Ambivalenz eines Autonomisierungsprozesses', Zeitschrift für Pädagogik, 34, pp. 285-297.

Tenorth, H.-E. (2008) Geschichte der Erziehung. Einführung in die Grundzüge ihrer neuzeitlichen Entwicklung (4th ed.). Weinheim and München: Juventa. 


\section{Wieland Wermke and Tine S. Prøitz}

Terhart, E. (1998) 'Changing concepts of curriculum: from 'Bildung' to 'learning' to 'experience': developments in (West) Germany from 1960s to 1990', in Gundem, B.B. and Hopmann, S. (eds.), Didaktik and/or Curriculum. Frankfurt: Peter Lang, pp. 107-126.

Terhart, E. (2011) 'Lehrerberuf und Professionalität: Gewandeltes Begriffsverständnis Neue Herausforderungen', Zeitschrift für Pädagogik, 57, pp. 202-224.

Thiel, C. (2019) Lehrerhandeln zwischen neuer Steuerung und Fallarbeit. Professionstheoretische und empirische Analysen zu einem umstrittenen Verhältnis. Wiesbaden: SpringerVS.

Thue, F.W. (2017) 'Lærerrollen lag på lag - Et historisk perspektiv', Norsk pedagogisk tidsskrift, 101(01), pp. 92-116. doi: 10.18261/issn.1504-2987-2017-01-09.

Wermke, W. (2013) Development and autonomy. Conceptualising teachers' continuing professional development in time and space. Stockholm: Stockholm University.

Wermke, W. and Forsberg, E. (2017) The changing nature of autonomy. Transformations of the late Swedish teaching profession. Scandinavian Journal of Educational Research, 61(2), $155-168$.

Wermke, W. and Paulsrud, D. (2019) Autonomie im Lehrerberuf in Deutschland, Finnland und Schweden: Entscheidungen, Kontrolle, Komplexität. Münster:Waxmann Verlag.

Wermke, W. and Prøitz, T.S. (2019) 'Discussing the curriculum - Didaktik dichotomy and comparative conceptualisations of the teaching profession', Education Inquiry, 10(4), pp. 300-327. doi: 10.1080/20004508.2019.1618677.

Wermke, W. and Salokangas, M. (2021) The autonomy paradox: teachers' perceptions of selfgovernance across Europe. Berlin: Springer Nature. 